\title{
The Pattullo Conference: Building Community Through Mentoring
}

\author{
BY KIM MARTINI, ELEANOR FRAJKA-WILLIAMS, AND COLLEEN MOUW
}

"CAN I REALLY DO THIS?!"

Enthusiasm and doubt surrounded the junior women at the opening reception of the Pattullo Conference. As in other science and engineering fields, real and perceived challenges prevent many women from continuing careers in physical oceanography after graduate school, and we were gathered with senior scientists in the field to debunk the myths surrounding academic careers and help junior women understand the real challenges. Topics at the conference ranged from balancing work and family life to successfully funding research proposals. In this article, we-junior scientist attendeesshare some of our personal revelations, surprises, and perspectives about women in physical oceanography gained from this conference. We hope this article will provide insight into the benefits of a gender-specific mentoring event such as the Pattullo Conference, inform senior scientists about what they can do to strengthen the field for junior scientists, and provide guidance to our peers in all geosciences about their chosen careers.

Why is the physical oceanography community concerned with retaining women in the field? Since June Pattullo, the number of women obtaining PhDs in physical oceanography has dramatically increased. However, as in other science and engineering fields, the balance of female principal investigators does not reflect this increase. The problem does not seem to lie in recruiting women into the field, but rather in retaining those trained in physical oceanography. The barriers to success for women are varied. Many have historical and cultural roots that are hard to quantify. They include the demands of combining a family with a career, complications associated with dual-career couples, real and perceived sexism, and inadequate mentoring. The MPOWIR program seeks to improve the success of women in physical oceanography by providing early career resources and mentoring opportunities.

Recent studies consistently show that one indicator of an individual's success in science is whether or not that individual has a mentor or mentors (see Women Scientists in Industry - A Winning Formula for Companies, 1999). Several scientists at the Pattullo Conference relayed experiences where a seemingly small gesture by an individual played a significant role in determining where they are today. At the Pattullo Conference, the junior scientists identified four types of mentors most significant to their success:

- Advisor: A mentor who provides scientific knowledge and helpful career tips

- Promoter: A mentor who opens doors and creates opportunities, such as introductions to colleagues and inclusion on grant proposals

- Guide: A mentor who knows your strengths and weaknesses and can encourage you based on their personal knowledge

- Role Model: A mentor who exemplifies achievements and personal characteristics that you find important The idea of multiple mentors was stressed several times: a single individual (e.g., one's advisor) does not need to advise, promote, guide, and be a role model. Rather, multiple people through different stages in our careers can fill these roles (Olmstead, 1993; Nelson, 2003). Additionally, the presence of one woman in an academic department does not guarantee that she will be an appropriate role model for all the junior women at an institution 
(Handelsman et al., 2005). The Pattullo Conference offered an opportunity to engage in mentoring relationships with numerous senior and junior scientists from many institutions. As junior scientists, it is our responsibility to seek out, recognize, and nurture potential mentoring relationships.

During sessions at the Pattullo Conference, we were able to build mentoring relationships by sharing our research and discussing retention issues openly. The focus on professional development provided essential skills and built self-confidence. In terms of career preparation, the junior scientists were highly interested in the hiring process, negotiation, funding their own research programs, and how to successfully navigate the transitional postdoctoral years. Time and again, we heard the key to mastering the hiring process is preparation: applicants should maintain current Web sites with up-to- role of mentors is particularly important in this area, as they have the means to guide junior scientists in preparation and completion of successful grant proposals.

At the conclusion of the Pattullo Conference, the junior scientists concurred that they felt more confident about their futures in physical oceanography. The conference provided an environment where junior scientists could voice their concerns, learn from others' experiences, and build scientific connections with both their junior counterparts and senior researchers from outside their home institutions. The key advice was to do good science, believe in yourself, and be proactive in seeking the advice and mentors you need. Continuing the work begun at the conference, MPOWIR is initiating mentoring groups with periodic mentoring conference calls and e-mails, and is organizing informal gettogethers at research conferences.

This community mentoring benefits thinking, learning, or teaching that may or may not split along gender lines will ultimately strengthen the field of oceanography and all STEM (science, technology, engineering, and mathematics) fields. The Pattullo Conference is a first step toward continually improving the field of physical oceanography through innovation and diversity, and we hope that other disciplines will adopt a similar program for community mentoring. 尼

Kim I. Martini (martini@apl.washington. edu) is PhD Candidate, School of Oceanography, University of Washington, Seattle, WA, USA. Eleanor Frajka-Williams is PhD Candidate, School of Oceanography, University of Washington, Seattle, WA, USA. Colleen Mouw is Postdoctoral Research

Associate, Space Science Engineering Center, University of Wisconsin-Madison, Madison, WI, USA.

\section{REFERENCES}

Handelsman, J., N. Cantor, M. Carnes, D. Denton, E. Fine, B. Grosz, V. Hinshaw, C. Marrett, S. Rosser, D. Shalala, and J. Sheridan. 2005. More women in science. Science 309(5738):1,190-1,191, doi:10.1126/science.1113252.

Milem, J.F. 2003. The educational benefits of diversity: Evidence from multiple sectors. Pp. 126-169 in Compelling Interest: Examining the Evidence on Racial Dynamics in Higher Education, M. Chang, D. Witt, J. Jones, and K. Hakuta, eds, Stanford University Press, Palo Alto, CA.

Nelson, D.J. 2003. The standing of women in academia Chemical Engineering Progress 99(9):38S-41S. Available online at: http://cheminfo.chem. ou.edu/ djn/diversity/Pubs/CEP03Aug/p38S-41S. html (accessed January 22, 2009).

Olmstead, M. 1993. Mentoring new faculty: Advice to department chairs. CSWP Gazette 13(1):1. Available online at: http://faculty.washington. edu/olmstd/research/Mentoring.html (accessed January 22, 2009).

Women Scientists in Industry - A Winning Formula for Companies. 1999. Catalyst Publications, New York, NY, 60 pp. Available online at: http://www. catalyst.org/publication/73/women-scientistsin-industry-a-winning-formula-for-companies (accessed January 22, 2009). "diversity breeds creativity" - a diverse work force improves group problem solving (Milem, 2003). Different styles of 